\title{
Digital Transformation Methodology of Industrial Enterprises
}

\author{
Sirotkina N.V.* \\ Voronezh State Technical University \\ Voronezh, Russia \\ e-mail: docsnat@yandex.ru \\ Shkarupeta E.V. \\ Voronezh State Technical University \\ Voronezh, Russia \\ e-mail: $9056591561 @$ mail.ru \\ Shalnev O.G. \\ Voronezh State Technical University \\ Voronezh, Russia \\ e-mail: shog2003@mail.ru
}

\author{
Kolosova N.V. \\ Voronezh State Technical University \\ Voronezh, Russia \\ e-mail: docsnat@yandex.ru \\ Pereslavtseva I.I. \\ Voronezh State Technical University \\ Voronezh, Russia \\ e-mail: u00105@vgasu.vrn.ru \\ Popova O.A. \\ Voronezh State Technical University \\ Voronezh, Russia \\ e-mail: oapopova1979@gmail.com
}

\begin{abstract}
The digital transformation of production processes and business models, going hand in hand with the selection of appropriate technologies, can provide long-term solutions to the alarming economic problems of our time. The article raises theoretical and empirical issues related to the current and future state of industry before, during and after digital transformation. Under the digital transformation of industry, the authors of article understand the process of integrating digital technologies into all aspects of industry, requiring fundamental changes in technology, culture, operations and principles of creating new products and services. The study examined the content, goals and objectives, principles, main directions, tools and stages of digital transformation of industry. The systemic problems of digital transformation are identified, on the basis of which a general digital transformation scheme and digital business model are proposed. In the process of digital transformation, a special role is assigned to the head of digital transformation (CDTO. The presented developments will make it possible to comprehensively transform the industry on the basis of transition to new business models, communication channels with customers and suppliers, products, business and production processes, and corporate culture, which are based on fundamentally new approaches to data management using digital technologies, with the aim of significant increase of industrial efficiency and long-term sustainability.
\end{abstract}

Keywords - digital transformation, digitalization, industry, chief digital transformation officer, digital business-model.

\section{INTRODUCTION}

At present, it is becoming apparent that the main trend is the arrival of IT technologies in the industry, which will drastically reduce the cost of production. Not only machines, but also conveyors and entire plants should be integrated into one network. In addition, consumer and industrial goods will also be on the Internet (the so-called technology of "Internet of things", "industrial Internet of things").
Industry is on the verge of radical structural changes. Digital transformation carries both huge potential and serious challenges. The study of Roland Berger "Digital Transformation of Industry" [1], conducted in conjunction with the German Industry Federation (BDI), examined the causes of digitalization and its impact on industry in Germany and other European countries.

The overall economic effect of digitalization was also calculated. In particular, experts found that digitalization of industry until 2025 alone in Germany could create an additional potential for creating value of 425 billion euros. The total figure for Europe is 1.25 trillion euros. If the region fails to turn the transformation into its own advantage, its industry may suffer a total loss in a huge amount of 605 billion euros [2].

\section{MethodS AND MATERIALS}

The research methodology is based on existing theoretical developments in the field of innovation management, corporate governance, competency-based approach.

In the research process, the dialectical approach, system analysis methods, economic and mathematical methods of information analysis, strategic management methods, expert assessments, modeling, clustering, tools of fuzzy production cognitive maps, system-activity method, network analysis methods, value-oriented, cultural historical methods, methods of social constructivism, functional analysis, as well as the prognostic method, etc., which provides a high degree of validity and reliability of the main conclusions and results of study.

\section{RESULTS}

The digitalization indicators of Russian economy show a greater growth potential compared to the level of Internet 
penetration. For example, access to digital services in Russia and in the European Union according to a number of indicators: the share of electronic commerce in the total retail vol. (Russia $-4 \%$, EU $-7 \%$ ), the share of organizations using CRM systems (Russia - $13 \%$, EU - $26 \%$ ), the proportion of citizens who made purchases online (Russia $29 \%$, EU - $57 \%$ ), the proportion of citizens who received public services via the Internet (Russia - $29 \%$, EU - $48 \%$ ), the penetration of mobile Internet (Russia - $46 \%$, EU $63 \%$ ), smartphone penetration (Russia - $60 \%$, EU - $62 \%$ ), Internet penetration (Russia - $76 \%, \mathrm{EU}-84 \%$ ).

Thus, the Russian Federation has the necessary prerequisites for the active growth of digital economy [3].

State support programs for the development of innovation sector are actively implemented in the Russian Federation. In accordance with Decree of President of the Russian Federation dated May 7, 2018 No. 204, the national program "Digital Economy of Russian Federation" was reformatted by the government of Russian Federation into a national project and cascaded into six federal projects. The total funding will amount to 522 billion rubles ( $\$ 7.8$ billion) [4]

Due to the incompleteness of a number of tasks of the previous reforms, the remaining negative management practices at industrial enterprises reduce the opportunities for introducing modern digital technologies.

The purpose of this article is to develop conceptual and methodological aspects of digital transformation of industry, the results of which should be a significant increase in industrial efficiency, as well as achieving long-term sustainability and global competitiveness.

The evolution of digitalization of processes includes three stages: automation $\rightarrow$ digitalization $\rightarrow$ digital transformation. Automation is characterized by the introduction of IT solutions that repeat the existing processes. Digitalization improves existing processes by introducing IT; Lean methods for optimizing processes; process reengineering [5].

Thus, digitalization is "the use of digital technologies to increase the efficiency of company and improve the quality of life of its employees" [6].

With digital transformation, there is a sharp decrease in transaction costs due to the emergence of new activity models, primarily digital platforms; the combination of technology capabilities and traditional sphere of activity of organization leads to appearance of new products and processes with fundamentally different qualities [7].

According to R. King, FedEx Corporation's corporate vice president, "when we talk about digital transformation, we're not just talking about digitalization and automation. We have been doing this for many years. For us, transformation is a real transition from the old style of work to completely new methods" [8].

For some people, digital transformation is too often used synonym for IT strategy. For PwC [9], this concept goes beyond the simple use of new technologies. Digital transformation is a new way to solve problems, create a unique experience in interacting with customers and employees, and accelerate business efficiency. It has a huge impact on the human resources of organization.

In the context of general digitalization of socio-economic processes, the company's readiness to transform all processes, or the so-called "innovative maturity" [10], comes to the forefront, which is reflected in the system of indicators of methodology for assessing the innovative maturity of companies taking into account readiness for digital transformation. [11]:

The tasks of digital transformation of industrial enterprises

1. Transformation of management system using digital technologies, implementation and improvement of development and decision-making processes.

2. Development of strategic planning and forecasting, including resource planning.

3. Ensuring the maximum effect of the introduction of digital technologies (improving cost-effectiveness).

4. Realization of personnel potential (development of a mentoring culture, disclosure of personnel potential, development of targeted programs for staff motivation and saving and development of natural intelligence).

5. Formation of digital medium and digital competencies of personnel, development of professional development paths, increasing the involvement and willingness of employees to share the values and principles of corporate culture.

6. Realization of marketing and production potential, search for new partnerships.

7. Development of fair competition in the domestic market, horizontal communications, access to new markets: geographical, demographic and food.

8. Creation of system of corporate standards, product catalogs, standard successful Russian solutions for digital business transformation by industry.

9. Creation of effective mechanisms for data management, the transition to management and production processes based on data.

10. Increasing the level of demand for research and scientific developments and the degree of their implementation.

11. Strengthening security with digital transformation tools, including information.

The effects of digital transformation of industrial enterprises [12]:

1. Increasing revenue indicators, market share, customer satisfaction, expanding product range.

2. Improving efficiency and effectiveness: reducing costs or production costs, improving its quality, safety and labor productivity. 
3. Human capital development: staff training and development programs, employee satisfaction and involvement, employer rating.

4. Improving the efficiency of investment use, increasing the number of investment or startup projects or reducing the time needed to create and launch new products on the markets.

5. Effects at the mission level - digitalization of subject of the Russian Federation and country as a whole.

From the point of view of digital transformation, some organizations can be attributed to the category of companies aimed at increasing efficiency, which use digital assets to increase the efficiency and speed of their business [13]; others relate to modernization-oriented companies that are building up new competencies to modernize their business [14]; still others are among the reformers that change their core business models to restructure their business [15]; finally, another category is industry pioneers who enter new markets or develop new industries [16].

Organizations carry out large-scale initiatives, so for to get a clear idea of the threats and opportunities in advance is a good help for them in making informed decisions that provide a balance between innovation and risk appetite [17].

The list of tools that corporations can use depends on the stage of innovation and the cost of tools [18]. The largest number of tools is applicable at the stage of searching for ideas, the smallest - at the stage of scaling. If the company doesn't have a significant amount of financial resources, it can use inexpensive tools, for example, events for startups and idea contests. If the company has significant financial resources, it can use tools such as corporate venture fund, laboratories, etc. [6]. As promising areas in the innovative development of corporations, it's possible to single out the use of digital platforms, collaboration and others [19].

The programs (projects) of digital transformation of industrial enterprises include the following [20]:

- reengineering and digitalization of production processes;

- digital import substitution;

- digital twin products;

- digitalization of managerial functions;

- the creation of digital products;

- implementation of marketing potential;

- $\quad$ architecture and infrastructure;

- digital competencies of staff;

- information safety;

- organizational changes in the framework of digital transformation, etc.

In order to develop breakthrough innovations, companies turn to new management models, such as open innovation (collaboration with external partners), design thinking (developing new solutions focused on people's needs), corporate venture funds and incubators [21].

As a result of implementation of methodological approach to classify the tools and practices of corporate governance of open innovation, the tools of corporate open innovation (Table 1) were integrated with the resources for implementing the tool and stages of innovation.

TABLE I. CORPORATE OPEN INNOVATION TOOLS

\begin{tabular}{|l|l|}
\hline \multicolumn{1}{|c|}{ Company } & \multicolumn{1}{c|}{$\begin{array}{c}\text { Innovative development tools with a focus on open } \\
\text { innovation }\end{array}$} \\
\hline $3 \mathrm{M}$ & $\begin{array}{l}\text { Unique corporate culture of innovation support; startup } \\
\text { support tools; own developments; mergers and acquisitions; } \\
\text { R\&D financing; technical forum, etc. }\end{array}$ \\
\hline IBM & $\begin{array}{l}\text { Innovation Center, RSTL Laboratory and Science and } \\
\text { Technology Center; blockchain platform; accelerators, etc. }\end{array}$ \\
\hline Airbus & $\begin{array}{l}\text { Innovation centers; global network of aerospace accelerators } \\
\text { Airbus BizLab; venture company Airbus Ventures, etc. }\end{array}$ \\
\hline $\begin{array}{l}\text { "United Aircraft } \\
\text { PJSC }\end{array}$ & $\begin{array}{l}\text { Venture funds; interaction with universities; conducting } \\
\text { hackathons and competitions; creation of corporate sandbox, } \\
\text { etc. }\end{array}$ \\
\hline EFKO & Scouting; startup competition; accelerator; venture fund, etc. \\
\hline Rostec & $\begin{array}{l}\text { Unique technological competency management system; } \\
\text { Center for Open Innovation (COI); additional training courses } \\
\text { on the theory of solving inventive problems (TSIP), etc. }\end{array}$ \\
\hline
\end{tabular}

a. Source: drawn up by authors

Working in the field of high technologies, it is not enough to reach a certain level - Rostec create a system of continuous innovations. It is not enough to be a national leader - Rostec want to act globally. A large number of industries today is not an advantage - a portfolio of "smart" products is needed. Therefore, having completed collection and consolidation of disparate industrial assets in 2014, State Corporation Rostec moved to the stage of active growth which required actualization of the Development Strategy. The main task of the Corporation at the stage of active growth is to reach the scale of the leading global competitors. Going out to the scale is not only a matter of competitiveness but also the task of preserving Russia as a world technological leader.

According to a digital transformation study conducted by PWC in 2018 (in which 1,155 executives of manufacturing companies in 26 countries were surveyed), data were obtained according to which "only $10 \%$ of global manufacturing companies are "Digital Champions", with almost two-thirds who are only at the initial stage or haven't started their digital path at all.

According to the results of another study [25] conducted by KPMG in 2019, the following eight became the key technologies for digital transformation in Russia:

1) robotization (RPA);

2) Big data analysis and predictive analytics;

3) chat bots;

4) artificial intelligence (AI);

5) virtual and augmented reality VR/AR;

6) Internet of Things (IoT); 
7) optical recognition;

8) blockchain.

The primary task within the framework of the beginning of digital transformation of industry is the appointment of CDTO with the assignment of its corresponding functions and powers and the formation of Competence Center [23].

CDTO - is a conductor of single digital development policy; provides management of implementation of digital transformation projects; coordinates strategic documents and budgets for informational support and digital transformation; coordinates the structural divisions of digital transformation and digital development; organizes data management; forms the Competence Center, performs other tasks [19].

The functional structure of digital transformation unit includes: a project office for implementation of digital transformation and digital development projects (within the authority, subordinate institutions, and supervised sphere); Process Transformation Office to create digital products/services; data management office; center of competence (it's possible to use an external center) [24].

The digital transformation of industry is carried out in several successive stages:

1) positioning;

2) planning (formation of ideas);

3) testing (implementation of pilot projects on digital transformation);

4) scaling.

The general scheme of digital transformation is presented in Figure 1.

Based on the study, we can conclude that the digital transformation of industry is a complex social challenge that requires agreements between key stakeholders [20]: citizens, state and business.

Since digital transformation is a business transformation, the structure of industrial enterprises, infrastructure and corporate culture that existed before its implementation could become barriers to implementation.

The effects of digital transformation are not immediately apparent therefore targets are set for deadlines that take into account not only the direct implementation of digital transformation activities, but also the period for obtaining the result.

Additionally, a study of large companies was conducted champions of innovative maturity, taking into account readiness for digital transformation $[11,26]$.

The share of $\mathrm{R} \& \mathrm{D}$ expenditures in the revenue of champion companies was on average $16 \%$ for large (with revenues of more than 2 billion rubles), $12 \%$ for medium (revenue from 800 million to 2 billion rubles) and $19 \%$ for small companies (revenue up to 800 million rubles). The share of technological innovation costs in revenue amounted to an average of $23 \%$ for large, $26 \%$ for medium and $25 \%$ for small companies. The share of new products in revenue amounted to an average of $53 \%$ for large, $53 \%$ for medium and $64 \%$ for small companies [27].

\begin{tabular}{|c|c|c|c|}
\hline \multicolumn{4}{|c|}{ STRATEGIC VECTORS OF DEVELOPMENT OF INDUSTRIAL } \\
ENTERPRISES \\
\hline Increase of profit & $\begin{array}{c}\text { Growth of } \\
\text { market share }\end{array}$ & $\begin{array}{c}\text { Expansion of } \\
\text { partner } \\
\text { network }\end{array}$ & $\begin{array}{c}\text { The study of } \\
\text { demand, consumer } \\
\text { needs }\end{array}$ \\
\hline $\begin{array}{c}\text { Point of sales } \\
\text { and distribution } \\
\text { channels }\end{array}$ & $\begin{array}{c}\text { Introduction of } \\
\text { innovations }\end{array}$ & $\begin{array}{c}\text { Brand } \\
\text { recognition }\end{array}$ & Corporate culture \\
\hline
\end{tabular}

\begin{tabular}{|c|c|c|c|}
\hline \multicolumn{2}{|c|}{ DIGITAL OPPORTUNITIES } \\
\hline $\begin{array}{c}\text { Ecosystem for } \\
\text { customer } \\
\text { solutions }\end{array}$ & $\begin{array}{c}\text { Operating } \\
\text { ecosystem }\end{array}$ & $\begin{array}{c}\text { Technological } \\
\text { ecosystem }\end{array}$ & $\begin{array}{c}\text { Personnel } \\
\text { ecosystem }\end{array}$ \\
\hline \multicolumn{2}{|c|}{$\uparrow$} & \\
\hline
\end{tabular}

\begin{tabular}{|l|c|}
\hline \multicolumn{2}{|c|}{ DIGITAL INVESTMENTS } \\
\hline $\begin{array}{l}\text { Digital } \\
\text { culture }\end{array}$ & $\begin{array}{c}\text { Realization of innovative potential: operational and } \\
\text { systematic implementation of innovations, acceleration of } \\
\text { business cycle and the launch of new products on the market }\end{array}$ \\
\hline
\end{tabular}

Fig. 1. General scheme of digital transformation of industrial enterprises [6, 16]

\section{CONCLUSION}

Previous attempts to introduce information technologies in industry have led to the creation of disparate information systems and often duplicated, without changing, "paper" processes.

Digital transformation requires a different approach to the development of digital solutions, to processes, to implementation of changes, to culture. The new wave of digitalization should use not only new technical solutions, but first of all management technologies that allow keeping people's transformations in focus.

Digital transformation at the level of the whole Russian Federation is possible only with a new approach to roles in teams and the emergence of digital transformation teams uniting regions, municipalities, federal authorities, business and citizens [21].

\section{References}

[1] E. Müllera, H. Hopfa, "Competence Center for the Digital Transformation in Small and Medium-Sized Enterprises", Proc. Manufactur., vol. 11, pp. 1495-1500, 2017, Retrieved from: https://doi.org/10.1016/j.promfg.2017.07.281.

[2] A. Issa, B. Hatiboglu, A. Bildstein, T. Bauernhaus, "Industrie 4.0 roadmap", Framework for digital transformation based on the concepts of capability maturity and alignment, vol. 72, pp. 973-978, 2018, Retrieved from: https://doi.org/10.1016/j.procir.2018.03.151 [Procedia CIPR].

[3] P. Verhoefa, T. Broekhuizena, Y. Bartb, A. Bhattacharyaa, J. Donga, N. Fabiana, M. Haenleinc, "Digital transformation: A multidisciplinary reflection and research agenda”, J. of Busin. Res., 2019. Retrieved from: https://doi.org/10.1016/j.jbusres.2019.09.022.

[4] I. Mergel, N. Edelmann, N. Haug, "Defining digital transformation: Results from expert interviews", Government Inform. Quarterly, vol. 36, no. 4, 2019. Retrieved from: https://doi.org/10.1016/j.giq.2019.06.002.

[5] T. Tolstykh, D. Savon, A. Safronov, E. Shkarupeta, T. Ivanochkina, "Methods and models for analysis the effectiveness of industrial 
enterprises", pp. 7710-7722, 2018 [Proc. of the 32nd Int. Business Information Management Association Conf. IBIMA 2018 - Vision 2020: Sustainable Economic Development and Application of Innovation Management from Regional expansion to Global Growth]

[6] Y. Salikov, I. Logunova, I. Kablashova, "Trends in human resource management in the digital economy", Proc. of the Voronezh State Univer. of Engineer. Technol., vol. 81, no. 2, pp. 393-399, 2019. Retrieved from: https://doi.org/10.20914/2310-1202-2019-2-393-399.

[7] N. Serebryakova, I. Avdeev, "The content of structural transformations of the region's economy, adequate to the requirements of digitalization", Proc. of the Voronezh State Univer. of Engineer. Technol., vol. 80, no. 4, pp. 408-412, 2018. Retrieved from: https://doi.org/10.20914/2310-1202-2018-4-408-412.

[8] N. Sirotkina, O. Stukalo, N. Nikitina, A. Chudaeva, "Networks of competences of subjects of the local food market in the conditions of formation of digital economy", Advan. in Intellig. Syst. and Comput., vol. 908, pp. 419-425, 2020.

[9] P.C. Verhoef, T. Broekhuizen, Y. Bart, A. Bhattacharya, J. Qi Dong, N. Fabian, M. Haenlein, "Digital transformation: A multidisciplinary reflection and research agenda", J. of Busin. Res., 2019. Retrieved from: https://doi.org/10.1016/j.jbusres.2019.09.022.

[10] B. Tronvoll, A. Sklyar, D. Sörhammar, C. Kowalkowski, "Transformational shifts through digital servitization", Industrial Market. Manag.t, 2020. $\quad$ Retrieved from: https://doi.org/10.1016/j.indmarman.2020.02.005.

[11] N. Durão, M. João Ferreira, C. Santos Pereira, F. Moreira, "Current and future state of Portuguese organizations towards digital transformation", Proc. Computer Sci., vol. 164, pp. 25-32, 2019. Retrieved from: https://doi.org/10.1016/j.procs.2019.12.150.

[12] K.S.R. Warner, M. Wäger, "Building dynamic capabilities for digital transformation: An ongoing process of strategic renewal", Long Range Planning, vol. 52, no. 3, pp. 326-349, 2019. Retrieved from: https://doi.org/10.1016/j.lrp.2018.12.001.

[13] Ch.-Ch. $\mathrm{Ku}$, Ch.-F. Chien, K.-T. Ma, "Digital transformation to empower smart production for Industry 3.5 and an empirical study for textile dyeing", Comput. \& Industrial Engineer., vol. 142, 2020. Retrieved from: https://doi.org/10.1016/j.cie.2020.106297.

[14] A. Singh, P. Klarner, T. Hess, "How do chief digital officers pursue digital transformation activities? The role of organization design parameters", Long Range Planning, 2019, Retrieved from: https://doi.org/10.1016/j.lrp.2019.07.001.

[15] Z. Tekic, D. Koroteev, "From disruptively digital to proudly analog: A holistic typology of digital transformation strategies", Busin Horizons, vol. 62, no. 6, pp. 683-693, 2019. Retrieved from: https://doi.org/10.1016/j.bushor.2019.07.002.
[16] K. Sandkuhl, N. Shilov, A. Smirnov, "Facilitating Digital Transformation by Multi-Aspect Ontologies: Approach and Application Steps", IFAC-PapersOnLine, vol. 52, no. 13, pp. 1609-1614, 2019. Retrieved from: https://doi.org/10.1016/j.ifacol.2019.11.430

[17] M. Fischer, F. Imgrund, C. Janiesch, A. Winkelmann, "Strategy archetypes for digital transformation: Defining meta objectives using business process management", Inform. \& Manag., 2020. Retrieved from: https://doi.org/10.1016/j.im.2019.103262.

[18] G. Vial, "Understanding digital transformation: A review and a research agenda”, J. of Strategic Inform. Syst., vol. 28, no. 2, pp. 118-144, 2019 Retrieved from: https://doi.org/10.1016/j.jsis.2019.01.003.

[19] G. Gupta, I. Bose, «Digital transformation in entrepreneurial firms through information exchange with operating environment», Information \& Management, 2019, Retrieved from: https://doi.org/10.1016/j.im.2019.103243.

[20] S. ElMassah, M. Mohieldin, "Digital transformation and localizing the Sustainable Development Goals (SDGs)", Ecolog. Econ., vol. 169, 2020 Retrieved from: https://doi.org/10.1016/j.ecolecon.2019.106490.

[21] M. José Sousa, Á. Rocha, "Digital learning: Developing skills for digital transformation of organizations", Future Generat. Computer Syst., vol. 91, pp. 327-334, 2019. Retrieved from: https://doi.org/10.1016/j.future.2018.08.048.

[22] D. Ulas, "Digital Transformation Process and SMEs", Proc. Computer Sci., vol. 158, pp. 662-671, 2019. Retrieved from: https://doi.org/10.1016/j.procs.2019.09.101.

[23] M. Güler, G. Büyüközkan, “Analysis of Digital Transformation Strategies with an Integrated Fuzzy AHP-Axiomatic Design Methodology", IFAC-PapersOnLine, vol. 52, no. 13, pp. 1186-1191, 2019. Retrieved from: https://doi.org/10.1016/j.ifacol.2019.11.359.

[24] N. Oertwig, P. Gering, T. Knothe, S.O. Rimmelspacher, "User-Centric Process Management System for Digital Transformation of Production", Proc. Manufactur., vol. 33, pp. 446-453, 2019. Retrieved from: https://doi.org/10.1016/j.promfg.2019.04.055.

[25] M. Ossewaarde, "Digital transformation and the renewal of socia theory: Unpacking the new fraudulent myths and misplaced metaphors", Technol. Forecast. and Soc. Change, vol. 146, pp. 24-30, 2019. Retrieved from: https://doi.org/10.1016/j.techfore.2019.05.007.

[26] S. Chanias, M.D. Myers, T. Hess, "Digital transformation strategy making in pre-digital organizations: The case of a financial services provider", J. of Strategic Inform. Syst., vol. 28, no. 1, pp. 17-33, 2019 Retrieved from: https://doi.org/10.1016/j.jsis.2018.11.003.

[27] N.C. Jackson, "Managing for competency with innovation change in higher education: Examining the pitfalls and pivots of digital transformation", Busin. Horizons, vol. 62, no. 6, pp. 761-772, 2019. Retrieved from: https://doi.org/10.1016/j.bushor.2019.08.002. 